\section{Comparison of clinical signs and bacterial isolates of postpartum endometritis in holstein dairy cows in Iran}

\author{
Mohammad Rahim Ahmadi, 1 \\ Masoud Haghkhah, 2 \\ Hamid Reza Gheisari, 3 Morteza Yavari1,4 \\ 1Department of Clinical Sciences; \\ 2Department of Pathobiology; \\ 3Department of Food Hygiene, School of \\ Veterinary Medicine, Shiraz University, \\ Shiraz; 4Department of Veterinary \\ Medicine, Bu-Ali Sina, Hamadan \\ University, Hamadan, Iran
}

\section{Abstract}

The aim of this study was to determine the uterine bacteria in cows with endometritis and to compare other characteristics in cases of endometritis without bacterial growth, with Trueperella pyogenes (Arcanobacterium pyogenes) or other bacteria. In total, 86 Holstein cows with postpartum endometritis from 13 commercial dairy herds were sampled once between 21-35 days postpartum. We used several diagnostic techniques for endometritis such as external observation, vaginal exam, rectal palpation, ultrasonography, and cervical and uterine cytological examination. Clear mucus with flakes of pus (E1), mucopurulent discharge (E2), and purulent discharge (E3) are three groups of endometritis. A transcervical double-guarded swab was used for bacterial sampling. The samples were cultured aerobic and anaerobically and biochemical tests were used for differentiation. Measurements were compared between groups: A, no growth (n=47); B, positive bacterial growth without $T$. pyogenes $(\mathrm{n}=21)$; and $\mathrm{C}$, positive bacterial growth with $T$. pyogenes $(\mathrm{n}=18)$. There were no differences $(\mathrm{P}>0.05)$ in uterine wall thickness, body condition score (BCS) and milk yield between the groups. The uterine horn diameter was largest in groups A $(4.30 \pm 0.88)$ in comparison with groups $\mathrm{B}(4.81 \pm 1.17)$ and $\mathrm{C}$ $(5.53 \pm 2.17)(\mathrm{P}<0.05)$. The percentage of neutrophiles in smears of the uterine discharge $(45.7 \pm 33.4)$ in group $\mathrm{C}$ was higher $(\mathrm{P}<0.05)$ than in groups A $(14.5 \pm 22.7)$ and $B$ (23.5 \pm 24.0$)$. Eighty-three percent of group C have shown purulent discharge. In conclusion, the facultative anaerobe $T$. pyogenes may be the most common bacterial agent of postpartum endometritis in Holstein dairy cows in Iran.

\section{Introduction}

A recent approach classifies endometritis into two categories, clinical and subclinical.1,2 Clinical endometritis is defined as the presence of purulent or mucopurulent uterine discharge detectable externally or in the anterior vagina and/or a cervical diameter greater than $7.5 \mathrm{~cm}$ after 26 days in milk (DIM). ${ }^{1}$ Subclinical endometritis is defined as the presence of polymorphonuclear leukocytes (PMN) in uterine cytology samples and/or ultrasonographic imaging of fluid in the uterine lumen after 21 days postpartum in the absence of clinical endometritis. ${ }^{2}$

The varying degrees of endometritis can cause a significant proportion of reproductive disorders. Endometritis is a common reproductive disorder in female domestic animals with a wide range of symptoms including no effect on reproductive performance to permanent infertility. Endometritis affects animals general health and strongly effects their reproductive performance. The lactational incidence of endometritisis has been reported from 7.5 to $61.6 \% .^{3}$ Transrectal uterine palpation, vaginoscopic test, uterine fluids cultivation, uteri biopsy and uteri cytology, and also various sampling after birth that have a role in definition of disorder and founding treatment option, are some diagnostic techniques which are used in endometritis cases. ${ }^{1}$ According to uterine cytological test the subclinical endometritisis is common in dairy cows and has a profound negative impact on reproductive performance. 4 Subclinical endometritis may occur in many postpartum cows that were previously presumed to be normal. Subclinical endometritis leads to poor reproductive performance in cows. ${ }^{2}$

Inflammation, histological lesions of the endometrium and delayed uterine involution are some symptoms of the presence of bacteria in uterus. 5 Furthermore, uterine bacterial infection or bacterial products suppress pituitary LH secretion and disturb growth of postpartum ovarian follicle and its function, which disrupts ovulation in cattle. ${ }^{6}$ Therefore, endometritis is associated with lower mating rates, increased intervals from calving to first service or conception, and more culls for lack of conception. 1,7

The aim of this study was to determine the uterine bacterial type in cows with postpartum endometritis and to compare other clinical characteristics in cases of postpartum endometritis without bacterial growth, with Trueperella pyogenes (Arcanobacterium pyogenes) or other bacteria in Holstein dairy cows in Iran.
Correspondence: Mohammad Rahim Ahmadi, Department of Clinical Sciences, School of Veterinary Medicine, Shiraz University, P.0.Box:71345-1731, Shiraz, Iran.

Tel.: +98.9177001074.

E-mail rahmadi@shirazu.ac.ir

Key words: Clinical endometritis; Bacteria; Trueperellapyogenes; Vaginal discharge.

Contributions: the authors contributed equally.

Conflict of interest: the authors declare no potential conflict of interest.

Received for publication: 23 June 2015.

Revision received: 25 August 2015.

Accepted for publication: 1 September 2015.

This work is licensed under a Creative Commons Attribution NonCommercial 4.0 License (CC BYNC 4.0).

(C) Copyright M.R. Ahmadi et al., 2017

Licensee PAGEPress srl, Italy

Veterinary Science Development 2017; 7:6083

doi:10.4081/vsd.2016.6083

\section{Materials and Methods}

\section{Animals}

This study was conducted on 13 big commercial dairy herds of Iran. Four hundred and two postpartum dairy cows were examined once between 21 and 35 days after birth. Totally, 86 cows that had clinical endometritis were selected. Cattle were calved in calving boxes hygienically and kept in single boxes for at least 10 days after delivery. The ration that was used for cows nutrition was a combination of corn silage, alfalfa hay, and concentrates. In this research, we did not use any intrauterine or reproductive hormonal therapy at least 10 days before sampling in cattle.

\section{Clinical examination}

At first, during the test cattle were investigated inorder to find fresh discharge on the vulva, perineum, or tail. If no discharge was visible externally, cows were investigated vaginally. The cow's vulva was cleaned completely using dry paper towel and then a clean, lubricated, gloved hand was inserted via the vulva. Lateral, dorsal and ventral walls of the vagina of each cow were examined and then the mucus contents withdrawn manually for test. ${ }^{8}$ The color and pus ratio of vaginal mucus were examined. Clear mucus with flakes of pus (E1), mucopurulent discharge or fluctuating contents in uteri (E2), and purulent discharge with or without palpable contents in uterus (E3) are three groups of endometritis. ${ }^{9}$ 
Following the investigation, transrectal palpation of the reproductive tract was done. Some features such as cervical diameter, location of the uterus, symmetry of the uterine horns, diameter of the (larger) uterine horn, texture of uterine wall, palpable uterine lumen, dominant palpable ovarian structure including corpus luteum (CL), follicle or no palpable structures were recorded. ${ }^{1}$

Ultrasonographic evaluation of uterus and ovaries was performed using a $5 \mathrm{MHz}$ rectal linear probe (AMI Company, Canada). Some parameters were measured in cows, such as Diameter of the uterus, echotexture and thickness of the uterine wall and intraluminal fluid accumulation. The overall shape of ovaries was scanned. 10

\section{Collecting uterine swab and bacte- riological culture}

For each cow, a transcervical protected swab was collected from body of uterus. The swab was comprised of a long copper wire bearing a cotton wool tip sheathed in a metal guard tube (8 $\mathrm{mm}$ external diameter; $58 \mathrm{~cm}$ long), and was wrapped and sterilized at $121^{\circ} \mathrm{C}$ for $15 \mathrm{~min}$ by autoclaving. The guard tube was covered with sterile plastic sheath in order to prevent contamination of the swab during the cervix insertion.

The cow was restrained and its tail secured and then the perineal region was washed and cleaned. Firstly, the cervix was differentiated from rectum and then a sterilized catheter was passed via the cervix into body of uteri. For sampling, the inner rod of catheter was pushed forward in order to expose the swab to endometrium, the swab was rotated opposite the uterine wall and finally withdrawn within the catheter. The catheter was cleaned with alcohol to avoid contamination. Swabs were cultured on sheep blood agar and MacConkey agar (MERCK) immediately, and incubated at $37^{\circ} \mathrm{C}$ for $48 \mathrm{~h}$. The same cultivation on sheep blood agar (MERCK) was incubated anaerobically for up to 7 days. Samples were isolated and identificated using standard biochemical tests. 11 Results of bacteriological cultivation were categorized in three groups: $A$, no growth; B, positive bacterial growth without T.pyogenes; and $\mathrm{C}$, positive bacterial growth with T.pyogenes.

\section{Cervical and uterine cytology}

Cytological samples were kept from discharge of cervical mucus and uterine fluid. Samples could be collected by two methods: i) gentle suction from the cervical external and ii) with a plastic pipette, then samples were aspirated by suction with a $50 \mathrm{~mL}$ syringe. ${ }^{12}$ Each uterine swab was used for bacteriological culture and cytological examination. After the samples had been taken the swabs were rolled on glass slides.

Thin smears were prepared for cytological test by smearing a drop of cervical mucus on a clean slide and then left to dry at room temperature for 30-35 minutes. Slides were moved to laboratory and examined within two hours after collection. Giemsa-stained slides were used for differential cell count of each smear in each of the 20 microscopic fields ( 900$) ; 100$ to 200 cells were counted. Types of recorded cells were epithelial, large vacuolated epithelial, neutrophiles, lymphocytes and macrophages. ${ }^{13}$

\section{Blood sampling and P4 assays}

Blood samples were collected from the artery or coccygeal vein into evacuated tubes and moved on ice to the laboratory. Blood serum was separated by centrifugation at 2500 $\times \mathrm{g}$ for 10 minutes and then stored at $-20^{\circ} \mathrm{C}$ until required. Radioimmuno assay was used to measure plasma progesterone concentration (Spectria ${ }^{\circledR}$ Progesterone RIA, Espoo, Finland) with a sensitivity of $0.1 \mathrm{ng} / \mathrm{mL}$ and intra- and inter-assay coefficients of variation of 10.2 and $6.5 \%$ respectively.

\section{Statistical analysis}

SAS software, version 9.1 was used for data analysis. T test and One Way ANOVA were used for comparison of cervical and uterine cells of endometritic cows with different discharges. To determine significant difference between groups, Duncan multiple range test was used as a post hoc test. Chi-square and Fisher exact tests were used to determine association of ovarian structure, P4 level of serum and discharge status with bacterial culture results in postpartum endometric cows. $\mathrm{P}<0.05$ was considered as a level of significance.

\section{Results}

The uterine horn diameter was higher in group C $(5.53 \pm 2.17)$ compared to A $(4.30 \pm 0.88)$ and $B(4.81 \pm 1.17)$ groups. The percentage of neutrophils in smears of the cervical mucosa and uterine discharge in group $\mathrm{A}$ $(14.5 \pm 20.6,14.5 \pm 22.7)$ and $\mathrm{B}(12.7 \pm 17.4$, $23.5 \pm 24.0)$ was lower than group C $(26.7 \pm 22.4$, $45.7 \pm 33.4)$. There were no differences in uterine wall thickness, body condition score (BCS) and milk yield between the groups (Table 1).

There was a significant difference between the uterine horn diameter and the size difference between the left and right uterine horns in cows with endometritis category E3 $(5.47 \pm 2.15)$ compared to category E1 $(4.34 \pm 0.91)$ and E2 $(4.81 \pm 1.17)$. The percentage of neutrophiles in smears of the cervical mucosa $(28.05 \pm 26.81)$ and uterine discharge $(42.70 \pm 30.93)$ in group E3 was higher
$(\mathrm{P}<0.05)$ than group E1 $(12.65 \pm 18.37$, $16.27 \pm 23.86)$ and group E2 $(14.92 \pm 10.92$, $27.36 \pm 31.91)$ respectively. There were no differences in uterine wall thickness, palma P4 concentration, BCS, parity and milk yield between the groups (Table 2).

Eightythree percent of group C showed purulent discharge. There was no significant difference between the cervical and uterine cytology of the endometritic cows. There was a significant difference between the same cells in different status of uterine discharge (Tables 1-3). Ovarian characters and P4 level of serum were independent from the bacterial culture results (Table 3). Vaginal mucus characters were compared with bacterial culture results (Table 4).

\section{Discussion and Conclusions}

The objective of this study was to compare bacterial growth and clinical characters, in cases of affected, to postpartum endometritis. Higher uterine horn diameter and percentage of neutrophiles in cervical and uterine mucosa in cows with endometritis grade 3 were shown in our study. Similarly, Westermann and colleagues ${ }^{14}$ found a significant positive correlation between findings of T. pyogenes and PMN, but not between other bacteria and PMN. The results of one sample may not give an accurate picture of the infection status. ${ }^{15}$ However, the intrauterine bacterial infection does not necessarily mean a clinical manifestation of disease; this depends on the immune status of the host. ${ }^{16}$ The uterine bacterium in cattle with postpartum endometritis was evaluated. The clinical severity and other characteristics in cases of postpartum endometritis without bacterial growth, and with Trueperella pyogenes or other bacteria in Holstein dairy cows in Iran were compared.

Postpartum endometritis has a negative effect on the reproductive performance, such as increased services per mating, the calving to first service interval and the calving to conception interval, 17 reducing the pregnancy ratio, ${ }^{1}$ and decreasing the conception rate. ${ }^{18}$ It is beleived that $T$. pyogenes is the most severe pathogen of the genital tract, and is rarely isolated alone in the postpartum period.1,19 In the first few days after calving, $E$. coli is dominant in the uterus and T. pyogenes is found later in animals with severe clinical endometritis. ${ }^{7}$ Various research have confirmed that most of the clinical and reproductive aftermath are related to the presence of certain and non-specific pathogens: mainly to $T$. pyogenes, either singly or along with other bacteria such as $E$. coli and gram negative obligate anaerobes. 16 Separation of T.pyogenes at the late involution period (28-35 days after calving) is related to 
significant reduction in re-conception rate. ${ }^{7}$ Trueperella pyogenes, E. coli, and non-differentiated streptococci, staphylococci and bacilli were the most commonly isolated bacteria in endometritis. ${ }^{20}$ Gram-negative anaerobes and other facultative pathogens including T. pyoge- nesare important pathogens that cause severe uterine inflammation. ${ }^{21}$ There is general agreement that $T$. pyogenes and $E$. coli are relevant uterine pathogens, T. pyogenes being the most frequently isolated species $\{$ LeBlanc, 2002 \#18692 \}. 16 Uterine pathogens, however, were also isolated from the uteri of cows that did not show clinical signs of endometritis. ${ }^{7}$ In accordance with previous reports $T$. pyogenes was the most prevalent bacteria in our study and positively related with vaginal discharge score, ${ }^{7,9}$ although $E$. coli is thought to play a

Table 1. Comparison of bacterial culture results and clinical characteristics of endometritis cows at 21-35 days in milk.

\begin{tabular}{|c|c|c|c|}
\hline Clinical characters & No growth $(n=47)$ & $\begin{array}{c}\text { Bacterial culture } \\
\text { Mixed growth }(n=21)\end{array}$ & Trueperella $(\mathrm{n}=18)$ \\
\hline BCS, $1-5$ & $2.82 \pm 0.31$ & $2.63 \pm 0.35$ & $2.69 \pm 0.28$ \\
\hline Larger uterine horn, $\mathrm{cm}$ & $4.30 \pm 0.88 \mathrm{a}$ & $4.81 \pm 1.17 \mathrm{ab}$ & $5.53 \pm 2.17 \mathrm{~b}$ \\
\hline Difference of 2 horns, cm & $1.16 \pm 0.69 \mathrm{a}$ & $1.52 \pm 0.80 \mathrm{a}$ & $2.33 \pm 1.67 \mathrm{~b}$ \\
\hline Uterine wall thickness, mm & $4.93 \pm 2.17$ & $5.26 \pm 1.76$ & $5.94 \pm 2.04$ \\
\hline Parity & $2.52 \pm 1.39$ & $2.94 \pm 1.92$ & $2.19 \pm 1.38$ \\
\hline Milk yield, $\mathrm{kg}$ & $29.84 \pm 10.90$ & $32.74 \pm 11.57$ & $32.31 \pm 9.55$ \\
\hline $\mathrm{P} 4, \mathrm{ng} / \mathrm{mL}$ & $1.22 \pm 1.63$ & $1.15 \pm 2.12$ & $1.39 \pm 2.23$ \\
\hline Cervical PMN, \% & $14.51 \pm 20.58 \mathrm{a}$ & $12.71 \pm 17.40 \mathrm{a}$ & $26.67 \pm 22.38 \mathrm{~b}$ \\
\hline Uterine PMN, \% & $14.54 \pm 22.70 \mathrm{a}$ & $23.55 \pm 24.04 \mathrm{a}$ & $45.73 \pm 33.41^{b}$ \\
\hline
\end{tabular}

Data are mean \pm standard deviation. Values with different superscript in the same row are significantly different.

Table 2. Comparison of endometritis classification and clinical characters of endometritis cows at 21-35 days in milk.

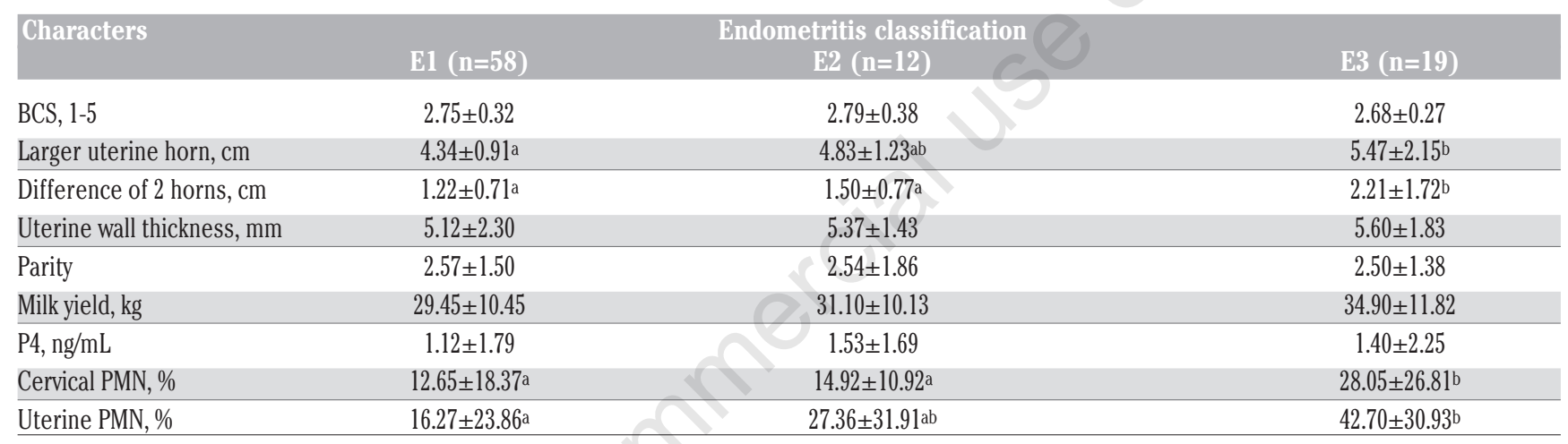

Data are mean \pm standard deviation. Values with different superscript in the same row are significantly different $(\mathrm{P}<0.05)$.

Table 3. Comparison of ovarian characters and clinical characters of endometritis cows at 21-35 days in milk.

\begin{tabular}{|c|c|c|c|}
\hline Characters & No structures $(\mathrm{n}=5)$ & $\begin{array}{l}\text { Ovarian characters } \\
\text { Follicle } \geq 8 \mathrm{~mm}(\mathrm{n}=57)\end{array}$ & Follicle + corpus luteum $(\mathrm{n}=27)$ \\
\hline BCS, 1-5 & $2.75 \pm 0.25$ & $2.66 \pm 0.30$ & $2.90 \pm 0.32$ \\
\hline Larger uterine horn, cm & $4.60 \pm 0.82$ & $4.71 \pm 1.50$ & $4.54 \pm 1.18$ \\
\hline Difference of 2 horns, $\mathrm{cm}$ & $1.80 \pm 0.57$ & $1.53 \pm 1.18$ & $1.28 \pm 0.90$ \\
\hline Uterine wall thickness, $\mathrm{mm}$ & $7.00 \pm 1.87 \mathrm{a}$ & $5.46 \pm 2.28 \mathrm{ab}$ & $4.52 \pm 1.37 \mathrm{~b}$ \\
\hline Parity & $3.67 \pm 2.52$ & $2.24 \pm 1.45$ & $3.00 \pm 1.38$ \\
\hline Milk yield, $\mathrm{kg}$ & $26.97 \pm 14.25$ & $30.01 \pm 10.76$ & $33.34 \pm 10.23$ \\
\hline $\mathrm{P} 4, \mathrm{ng} / \mathrm{mL}$ & $0.43 \pm 0.38 \mathrm{a}$ & $0.51 \pm 1.19 \mathrm{a}$ & $2.94 \pm 2.12 \mathrm{~b}$ \\
\hline Cervical PMN, \% & $14.60 \pm 19.33$ & $18.91 \pm 22.78$ & $10.92 \pm 14.09$ \\
\hline Uterine PMN, \% & $45.20 \pm 42.27$ & $20.96 \pm 25.29$ & $23.20 \pm 30.55$ \\
\hline
\end{tabular}

Data are mean \pm standard deviation. Values with different superscript in the same row are significantly different $(\mathrm{P}<0.05)$.

Table 4. The relationship between microbial growth and vaginal discharge.

\begin{tabular}{lcccc} 
Bacteria & \multicolumn{3}{c}{$\begin{array}{c}\text { Vaginal mucus character } \\
\text { Mucopurulent }\end{array}$} & Purulent \\
No growth, (\%) & $40(46.51)$ & $6(6.97)$ & $1(1.16)$ & $47(54.65)$ \\
Mixed growth (\%) & $13(15.11)$ & $5(5.81)$ & $3(3.49)$ & $21(24.41)$ \\
\hline Arcano. (\%) & $2(2.32)$ & $1(1.16)$ & $15(17.44)$ & $18(20.93)$ \\
Total (\%) & $55(63.95)$ & $12(13.95)$ & $19(22.09)$ & $86(100)$ \\
\hline
\end{tabular}

There was significant difference $(\mathrm{P}<0.0001)$ between vaginal mucus character groups. 
key role in the metritis-endometritis complex.9,22 To determine the origin of exudates (which may stem from the uterus, cervix, or vagina) the vaginal speculum test can help. ${ }^{9}$ Some researchers reported that the most useful tool for the diagnosis of endometritis is vaginoscopy for detection of pus and cervical contents, 1,3 while Sheldon and Dobson ${ }^{23}$ confirmed that the most useful method for diagnosis of endometritis is the examination of the contents of the vagina for the presence of pus. In the present study, we compared bacterial isolation and the vaginal mucus characters. Positive results from bacterial culture were more commonly associated with mucopurulent or purulent vaginal mucus. These observations are in agreement with Williams and colleagues. 9 They reported that the bacterial growth densities for recognized and potential pathogens were associated with purulent vaginal mucus, and higher growth density for recognized pathogens was associated with mucopurulent mucus character. Pus is a combination of bacterial infection and a mixture of viable and dead neutrophil leucocytes, necrotic tissue and tissue fluid, so it is not surprising that bacterial growth density of pathogenic bacteria is associated with purulent vaginal mucus. ${ }^{9}$ The associations found between a vaginoscopy examination performed 28-37 days prior to Mating start date and subsequent reproductive performance indicate that vaginoscopy is an effective tool for predicting cows with reduced odds of pregnancy rate. ${ }^{24}$

There were also significant differences in neutrophils percentages between different groups of bacterial culture results and between different grades of endometritis severity, however, the results of this study support that the increase in neurophils percentage in uterine fluid was in accordance with the increase of neurophils percentage in cervical mucosa. The results of this study also revealed that the contamination of uterus with $T$. pyogenes causes increased neutrophils to migrate to the uterus, and the severity of endometritis. The color of normal discharge ranged from dark brown to red or white and usually should not be considered abnormal unless there are other aberrant clinical signs or if the discharge is malodorous. ${ }^{1}$ Presence of a white or whitish-yellow mucopurulent vaginal discharge is one of the symptoms of endometritis. ${ }^{8}$ The volume of the discharge is variable, but increases at estrus stage when the cervix dilates and there is great vaginal mucus. The uterine PMN\% was a better predictor of reproductive performance than either intra-uterine bacteriology or gross vaginal inflammation score. ${ }^{25}$ Cows in the highest quartile for PMN\% at both days 28 and 42 had lower pregnancy rates, took longer to conceive, and had a lower milk yield than those in the lower PMN\% categories.

It is believed that the uterus is less sensitive to invasion by pathogens or experimental bacterial challenge after delivery in animals until the first ovulation, and during the follicular phase of the next cycles. In a model study 26 progesterone treatment increased the susceptibility of animals to intrauterine inoculation with T.pyogenes and $E$. coli, and also reduced the circulating PGF2, and elevated the plasma PGE2 for a few days after treatment. Using concanavalian (A-stimulated lymphocyte proliferation) measurement we found that ovariectomy increased and progesterone treatment decreased the cellular immune response.26,27 Progesterone makes the uterus susceptible to infection after calving, ovariectomy allows the dam to maintain resistant, and prostaglandins of uterus may mediate the process. ${ }^{26,27}$ In conclusion, the present study provides evidence that $T$. pyogenes may be the most common bacterial agent of postpartum endometritisin Iranian dairy farms. Choice treatment of postpartum cows affected by $T$. pyogene scan reduce the severity of endometritis, prevent chronic endometritis and repeat breeder cows. Consequently, more study needs to be done to detect the relationship between T. pyogenes and infertility in dairy cows.

\section{References}

1. Kasimanickam R, Duffield TF, Foster RA, et al. Endometrial cytology and ultrasonography for the detection of subclinical endometritis in postpartum dairy cows. Theriogenology 2004;62:9-23.

2. Amiridis GS, Fthenakis GC, Dafopoulos J, et al. Use of cefquinome for prevention and treatment of bovine endometritis. $\mathrm{J}$ Vet Pharmacol Therapy 2003;26:387-90.

3. LeBlanc SJ, Duffield TF, Leslie KE, et al. Defining and diagnosing postpartum clinical endometritis and its impact on reproductive performance in dairy cows. J Dairy Sci 2002;85:2223-36.

4. Hammon DS, Evjen IM, Dhiman TR, et al. Neutrophil function and energy status in Holstein cows with uterine health disorders. Vet Immunol Immunopathol 2006;113:21-9.

5. Sheldon IM, Dobson H. Postpartum uterine health in cattle. Anim Reprod Sci 2004;82:295-306.

6. Opsomer G, Grohn YT, Hertl J, et al. Risk factors for post partum ovarian dysfunction in high producing dairy cows in Belgium: a field study. Theriogenology 2000;53:841-57.

7. Huszenicza G, Fodor M, Gacs M, et al. Uterine bacteriology, resumption of cyclic ovarian activity and fertility in postpartum cows kept in large-scale dairy herds. Reprod Domest Anim 1999;34:237-45.
8. Sheldon IM, Noakes DE, Rycroft AN, Dobson H. Effect of postpartum manual examination of the vagina on uterine bacterial contamination in cows. Vet Rec 2002;151:531-4.

9. Williams EJ, Fischer DP, Pfeiffer DU, et al. Clinical evaluation of postpartum vaginal mucus reflects uterine bacterial infection and the immune response in cattle. Theriogenology 2005;63:102-17.

10. Mateus L, Da Costa LL, Bernardo F, Silva JR. Influence of puerperal uterine infection on uterine involution and postpartum ovarian activity in dairy cows. Reprod Domest Anim 2002;37:31-5.

11. Quinn PJ, Carter ME, Markey BK, Carter GR. Clinical veterinary microbiology. St Louis, US: Mosby Wolfe; 1994.

12. Ahmadi MR, Nazifi S, Ghaisari HR. Comparative cervical cytology and conception rate in postpartum dairy cows. Vet Arch 2006;76:323-32.

13. Jain NC. Schalm's veterinary haematology. Philadelphia: Lea and Febiger; 1986.

14. Westermann S, Drillich M, Kaufmann TB, et al. A clinical approach to determine false positive findings of clinical endometritis by vaginoscopy by the use of uterine bacteriology and cytology in dairy cows. Theriogenology 2010;74:1248-55.

15. Griffin JF, Hartigan PJ, Nunn WR. Nonspecific uterine infection and bovine fertility: I. Infection patterns and endometritis during the first seven weeks post-partum. Theriogenology 1974;1:91-106.

16. Földi J, Kulcsár M, Pécsi A, et al. Bacterial complications of postpartum uterine involution in cattle. Anim Reprod Sci 2006;96:265-81.

17. Heuwieser W, Tenhagen BA, Tischer M, et al. Effect of three programmes for the treatment of endometritis on the reproductive performance of a dairy herd. Vet Record 2000;146:338-41.

18 Fourichon C, Seegers H, Malher X. Effect of disease on reproduction in the dairy cow: a meta-analysis. Theriogenology 2000;53:1729-59.

19. Zerbe H, Ossadnik C, Leibold W, Schuberth HJ. Influence of Escherichia coli and Arcanobacterium pyogenes isolated from bovine puerperal uteri on phenotypic and functional properties of neutrophils. Vet Microbiol 2001;79:351-65.

20. Yavari M, Haghkhah M, Ahmadi MR. Bacterial study of clinical postpartum endometritis in Holstein dairy cows. J Vet Res 2007;11:14-23.

21. Azawi OI, Omran SN, Hadad JJ. Clinical, bacteriological, and histopathological study of toxic puerperal metritis in Iraqi buffalo. J Dairy Sci 2007;90:4654-60.

22. Donofrio G, Ravanetti L, Cavirani S, et al. Bacterial infection of endometrial stromal 
cells influences bovine herpesvirus 4 immediate early gene activation: a new insight into bacterial and viral interaction for uterine disease. Reproduction 2008;136:361-6.

23. Sheldon I, Dobson H. Postpartum uterine health in cattle. Anim Reprod Sci 2004;82:295-306.
24. Runciman DJ, Anderson GA, Malmo J, Davis GM. Effect of intrauterine treatment with cephapirin on the reproductive performance of seasonally calving dairy cows at risk of. Aust Vet J 2008;86:250-8.

25. McDougall S, Hussein H, Aberdein D, et al. Relationships between cytology, bacteriology and vaginal discharge scores and reproductive performance in dairy cattle. Theriogenology 2011;76:229-40.

26. Lewis GS. Steroidal regulation of uterine resistance to bacteria infection in livestock. Reprod Biol Endocrinol 2003;1:117.

27. Lewis GS. Steroidal regulation of uterine immune defenses. Anim Reprod Sci 2004;82:281-94. 